\title{
An Almost Forgotten Jubilee - The 450th Anniversary of the Reformation through the Pages of Romanian Orthodox Press
}

\author{
Dragoş BoICU*
}

Remembering the events which happened 50 years ago, this paper will attempt to point out the specific way in which the Romanian Orthodox Church reported on the 450th anniversary of the Reformation. By going through the pages of Orthodox ecclesiastical periodicals that reported on this particular moment, a growing focus on the Ecumenical Movement and the dialogue partners of other denominations can be noted, marking a beneficial openness to knowledge and understanding of other Churches.

Keywords: Ecumenical Dialogue, Evangelical Church, Reformation, Romanian Orthodox Church

\section{Introduction}

The 500th anniversary of the publication in Wittenberg of Martin Luther's 95 theses written against fallacies within the Roman Catholic Church is the right moment for both retrospectives and projections for the future. It is clear that the beginning, marked by a relatively short time span, to clear and find a specific direction in European Christianity, the Evangelical Church was marked by an unprecedented openness and by developing a culture of dialogue and an authentic discovery of alterity or otherness.

Of course, this dialogue had its important moments, especially with regard to the Orthodox Church, although there were many interruptions, worsened by parallel agendas, which had nothing to do with the recognition of the Christian values of one another. In addition, the relations between Lutherans and Orthodox were marked by ethnic and religious tensions and discrimination. However, communication between the two families of Churches remained, even at the formal level, a constant that had dominated the ecclesiastical landscape of Sibiu, since the episcopate of the great Andrei Şaguna.

Naturally, a sensitivity was created and so began a beautiful tradition that the representatives of one confession take part in the significant events of the other Church, marking a modus vivendi permeated, at least formally,

\footnotetext{
* Dragoş Boicu, PhD, Teaching Assistant at the Andrei Șaguna Faculty of Orthodox Theology, Lucian Blaga University of Sibiu, Romania. Address: Str. Mitropoliei 20, 550179 Sibiu, România; e-mail: dragosbcu@yahoo.com.
} 
by a spirit of love and mutual respect. In this regard, I would like to bring attention to the participation of the Romanian Orthodox Church at the jubilee organised 50 years ago - in 1967 - which was dedicated to the 450th anniversary of the beginning of the Reformation.

But, when referring to the year 1967, we must remind ourselves of the political context that dictated the social and cultural orientations of that moment. More than two decades had passed since the end of the Second World War and since the establishment of Communism in Romania, which was proclaimed a popular republic 20 years ago, and its statute changed in 1965 when it became a Socialist republic. Freedom of movement and communication with the outside were heavily restricted, being constantly supervised by authorities and state institutions, while the few contacts kept with the West had to reflect the democratic character, successes and incredible resources of socialism.

Starting from these premises [the tradition of communion and the need to maintain the appearances of freedom within the ecclesiastical space], but also from the political reality of the inclusion of the German Democratic Republic in the Soviet bloc, we do not have to wonder about the participation of some representatives of the Romanian Orthodox Church at the anniversary of the Reformation. Instead, it is interesting to look at how the event was reflected in the Orthodox Church press.

By going through the pages of the main ecclesiastical publications in 1967, we are reminded of a series of recurring themes:

- the Vietnam war and a profound concern for the creation of a denuclearised area;

- the Fifth General Assembly of the European Churches' Conference - Nyborg V;

- the 90th anniversary of the proclamation of Romania's independence in 1877;

- the 450th Anniversary of the main church's inauguration from Curtea de Argeş in 1517;

- the death of Nicolae Colan, Metropolitan of Transylvania and the election of Archimandrite Nicolae Mladin as Metropolitan in his place;

- the visit to Romania of Athenagoras, the Ecumenical Patriarch;

- the 150th Anniversary of the Brukenthal Museum in Sibiu;

- the election of Nicolae Ceaussescu by the Grand National Assembly as president of the State Council.

To these are added topics specific to local chronicles, studies and the usual homiletic guidance, occasionally completed by reviews and notes. 
Given that censorship was omnipresent, and that concrete possibilities for editing these publications were limited, editorial effort for identifying and disseminating valuable content had become a constant concern. However, since international and local themes were quite numerous, news of the Evangelical Jubilee occupied quite a small space.

In fact, there are only some brief references in the periodicals: Glasul Bisericii, Studii Teologice, Biserica Ortodoxă Română, Ortodoxia, Mitropolia Banatului, Mitropolia Olteniei and Mitropolia Moldovei şi Sucevei. But, if we turn our attention from the quantitative to the qualitative aspect, we find surprises in the content. Surprisingly, we note from this list of periodicals, the absence of the publications printed in Sibiu, Mitropolia Ardealului and Telegraful Român. However, if we remember the events of 1967, we note that they emphasised two moments that marked the ecclesiastical life of Transylvania: the death of the Metropolitan Nicolae Colan, and the election and installation of Metropolitan Nicolae Mladin respectively.

\section{The actual anniversary}

By analysing the news about the 450th anniversary of the publication of Martin Luther's 95 theses, we can distinguish between neutral, brief notes, six or seven lines long, without details, published in the Glasul Bisericii ${ }^{1}$, Mitropolia Banatului ${ }^{2}$, Mitropolia Olteniei ${ }^{3}$ and some presentations of critical appreciations that developed the theme of the Reformation's importance, as we find in Biserica Ortodoxă Română $\breve{a}^{4}$ Studii Teologice ${ }^{5}$, Mitropolia Moldovei şi Sucevei ${ }^{6}$ and Ortodoxia .

According to these accounts, the 450th anniversary of the publication of Martin Luther's manifesto was celebrated

in the atmosphere of the general effort to bring people together to create a future of renewal, cooperation and peace. In the German

1 Orest Bucevsky, "Pentru pacea a toată lumea”, in: Glasul Bisericii 26 (11-12/1967), p. 1099.

2 S.n., "Sărbătoarea Reformei”, in: Mitropolia Banatului 17 (10-12/1967), p. 749.

3 T.N.M., "Bisericile Protestante - A 450-a aniversare a Reformei”, in: Mitropolia Olteniei 19 (7-8/1967), p. 981. The text follows mainly the events celebrated in France.

4 Il.I. Georgescu, "Împlinirea a 450 de ani de la începutul Reformei. Festivităţile din Republica Democrata Germana”, in: Biserica Ortodoxă Română 85 (9-10/1967), p. 939-941.

5 S.n., "Consideraţii asupra teologiei protestante după 450 de ani de la reformă”, in: Studii Teologice 19 (9-10/1967), p. 555-564.

6 Milan Şesan, “450 de ani de la Reforma lui Martin Luther”, in: Mitropolia Moldovei şi Sucevei 48 (11-12/1967), p. 678-680.

7 S.n., "Comemorarea Reformei şi năzuinţele ecumeniste contemporane", in: Ortodoxia 19 (4/1967), p. 490-493 
Democratic Republic, the home of Martin Luther and the place in which he carried out all his work, sumptuous festivities were organized between October 24 and November 3, 1967, where the representatives of the Christian Churches, delegates of world organizations, scientists and scholars were invited ${ }^{8}$.

The schedule was extremely tight, taking place in several stages and prepared by an international symposium on the World Importance of the Reformation (24-27 October). More than 130 specialists, theologians, historians, sociologists, philosophers and literati from 9 countries attended. After opening with a plenary session, the events continued on October 26 with the Magdeburg Symposium on the Importance of the Great Socialist Revolution of October in the struggle for peace, humanity and social progress?. The scientific session intertwined with solemn religious services, excursions, and an artistic program dedicated to the Reformation and Luther ${ }^{10}$.

For the participants "to be able to document Martin Luther's activity on site, on the 27th and 28th of October a great trip was organized at Halle, Wartburg Eisenach and Erfurt. On that occasion the city of Buchenwald was visited, where the Nazis had exterminated thousands of people. At that former concentration camp, it was stated that the Reformation cannot be used for fascist intents, but only to support actions that pursue the social and democratic good of the faithful" ${ }^{11}$.

Another phase of the festivities took place on the 29th-31st October, at which

over 180 guests of honour and over 1000 other guests from all the world's continents and from the important churches and local confessions participated. The Orthodox Church was present through delegates from the Autocephalous Orthodox Churches ${ }^{12}$, and from the Romanian Orthodox Church were present H.E. Iustin Moisescu, Metropolitan of Moldavia and Suceava, and Rev. Prof. PhD Milan Şesan; the Evangelical-Lutheran Church A.C. from the Socialist Republic of Romania was represented by $\mathrm{Mr}$ Prof. PhD Herman Binder, the Episcopal Vicar, and Pastor PhD Ludwig Binder ${ }^{13}$.

8 Il.I. Georgescu, "Împlinirea a 450 de ani", p. 939.

9 M. Şesan, “450 de ani”, p. 678.

10 Il.I. Georgescu, "Împlinirea a 450 de ani”, p. 940.

11 M. Şesan, “450 de ani”, p. 679.

12 Ibidem.

13 Il.I. Georgescu, "Împlinirea a 450 de ani de", p. 940. 
Between November 1st and $3^{\text {rd }}$, a session of theological and scientific studies on the many meanings of the Reformation took place ${ }^{14}$, in stark contrast to the atmosphere of 450 years ago.

Rev. Milan Şesan records the evolution of these anniversary moments, pointing out that, amid the numerous scandals

caused by the theological subjectivism, in 1817 , when the 300th anniversary of the Reformation was celebrated, the question of the unification of the Protestant branches was raised, and then in 1917, when 400 years were celebrated, the principle of the ecumenical and inter-Christian approach, with the Orthodox and the Roman Catholic Church was tackled ${ }^{15}$.

Now, conditions have evolved in such a manner that interconfessional dialogue is not only possible but also a natural step further along the path of mutual understanding:

the commemoration of the beginning of the Reformation has taken place in a new climate, animated by intentions entirely different from those that generated the Reformation and animated it throughout its development. [...] This new climate, which consists in the absence of the spirit of controversy and in the tendency to understand the values of the non-protestant Christian Churches, made it possible for this commemoration to be attended by the representatives of other Churches, especially the Roman Catholic Church and the Orthodox Church ${ }^{16}$.

The 450th anniversary of the publication of Luther's theses has supported a unanimous appreciation of the 16th century Reformation in its entirety, taking into account the historical circumstances in which it occurred, as well as the orthodox and the unorthodox positions of Luther and of other reformers. It also determined concrete references to the structure and form of the Lutheran and Protestant tradition in the context of Western Christianity. On the other hand, those elements of the theology of the Reformation that have a permanent significance for the entire Christian Church have been reaffirmed, elements which at that time could not be defined in convenient formulas for all $^{17}$.

Beyond the description of the event, the few more extensive presentations mentioned above reflect deeply the spirit of the epoch, the anniver-

\footnotetext{
14 Ibidem.

15 M. Şesan, “450 de ani”, p. 678.

16 S.n., "Comemorarea Reformei”, p. 489.

17 S.n., "Consideraţii asupra teologiei”, p. 557.
} 
sary being shadowed, or if we are allowed to say it more directly, hijacked by the political ideology that dominated at that time, the Soviet bloc, to which any academic and spiritual activity was formally subordinated in order to be able to pass through the censorship institutions of the communist regime.

Therefore, if we relate to these accounts in which we find the same pragmatic vision imposed by those times, it is necessary to see the context and the subtext which, like the other recurring themes of the previously mentioned religious publications, reflect the historical framework in which the Church seeks to find a safe place, immune to the pressures of the Soviet regime, in order to survive.

If we look at the political context of the 1960s, we can see a tendency to establish a common, anti-Catholic religious front that doubles and supports the ideology of the Soviet bloc so that churches from the popular, socialist or democratic "captivity" can be co-opted in the effort to combat the capitalist imperialism, whose main agent was the pope. That is why we are not surprised by the effervescence of the theological contributions published during the Second Vatican Council, in which the tendencies of papal absolutism are criticized with promptness and vehemence. In this theological and ideological war theology professors especially were engaged, among whom we mention the most ferocious anti-Catholic fighter of that period, Father Dumitru Stăniloae, newly released from the Aiud prison on January 15, 1963, following the pardon decree no. 5/1963, and reintegrated among the professors of the Theological Institute in Bucharest that same year.

Patriarch Teoctist said more than a decade ago that "during the Communist dictatorship (1948-1989), in Romania an ecumenism under the cross was developed, through meetings between the heads of religions and through inter-confessional theological conferences between the Orthodox, Roman Catholic and Protestant Theological Institutes, with the participation of professors, bishops and leaders of religious confessions. The resumption of these conferences on a new basis is a major requirement for the promotion of local ecumenism in Romania, initiated on common theological principles and responding to the current demands of the world"18.

Under this cross of pressure, on the eve of the Second Vatican Council, the Romanian Orthodox Church, together with the Moscow Patriar-

\footnotetext{
$18 \dagger$ †eoctist, "Exigenţele ecumenismului actual din punctul de vedere al Bisericii Ortodoxe Române”, Conference held at the University of Munich, 9 mai 2003. http://www.sfantulambrozie.ro/relatii-ecumenice/113-exigentele-ecumenismului-actual-din-punctul-de-vedereal-bisericii-ortodoxe-romane, viewed on 20.05.2017.
} 
chate, joined the World Council of Churches in $1961^{19}$, a structure in which the Roman Catholic Church is not part. As an irony of fate, at the Orthodox Conference in Moscow (July 9-18, 1948), a refusal to participate in the ecumenical movement through the Ecumenical Council of Churches constituted in that year (1948) was formulated, the organisation being accused of "too much concern for political and social life other than the creation of an Ecumenical Church as an international force, the lack of discussion of unity on doctrinal background, and the intention of Protestantism to oppose Catholicism by seeking an ally in the Orthodox Church, thereby assuring its international power" 20 .

Returning to the anniversary of 1967 , in the context of cultivating a dialogue with the other Churches, and especially with the Soviet bloc partners, we are not surprised to find appreciations such as that of Professor Milan Şesan, who noted that "the Wittenberg celebrations in honor of the Reformation also had the intention of bringing Christians closer to one another, in order to make a serious contribution to ensuring and strengthening world peace" 21 .

\section{Reflections on the Reformation}

Although the common thread connecting these materials is the significance of Martin Luther's action "for the subsequent evolution of society both on ecclesial and social level" 22 , we can distinguish different nuances that the authors have emphasized in the texts dedicated to the anniversary of 450 years since the Reformation, with peculiarities determined by the role of these periodicals.

It should be noted that from the terminological point of view, the authors of these texts make a permanent distinction between reform [rom. reformă] as a political, economic, social, cultural, limited or structural transformation, of a state of things in order to obtain an improvement or progress and Protestant reform as a movement of religious renewal, which we often find defined as Reformation [rom. Reformaţiune] ${ }^{23}$.

19 Formally, the adherence to the CMB is seen as a follow-up to the Christian unity initiative recommended by the Ecumenical Patriarch Athenagoras in 1950, and especially after the Pan-Orthodox Conference in Rodhos (24 September-1 October 1961).

20 Mihai Săsăujan, "Poziţia Bisericii Ortodoxe Române faţă de mişcarea ecumenică în perioada anilor 1902-1948”, in: Nicolae Moşoiu (ed.), Elemente de istorie, doctrină şi practică misionară: o perspectivă ecumenică, Sibiu 2006, p. 75.

21 M. Şesan, “450 de ani”, p. 680.

22 Il.I. Georgescu, "Împlinirea a 450 de ani", p. 941

23 I would especially like to thank the Rev. Prof. Dr. H.C. Viorel Ioniţă for pointing out this distinction. 
Thus, the material published in the Biserica Ortodoxă Română - the official bulletin of the Romanian Patriarchate - insists on this occasion on a very current theme at that time, namely: the revolutionary character of the moment in 1517:

The reform initiated by Martin Luther was a factor of progress for that time, opening the way for a new humanism and preparing the premises for further social transformations ${ }^{24}$.

The text refers to the idea of social revolution, and in this case Luther can be seen as the precursor of the socialist revolution, a subject that became the focus of many of the papers presented on this occasion. The participants

noted the importance of Martin Luther's action and its deep social implications for accomplishing the cooperative aspirations of all Christians in solving the current social problems. H.E. Justin, Metropolitan of Moldavia and Suceava stressed the importance of the Reformation for the evolution of Christianity because the German reformist militated both for religious and social reform ${ }^{25}$

by protesting against the social injustices of the time ${ }^{26}$.

The social implications of spiritual reform have been expressed throughout history in this way: "Martin Luther's action was an explosion of popular consciousness in the ongoing upheavals of the German people"27. Consequently, "the progressive atmosphere of socialism in which the working people of the German Democratic Republic live, somehow crowns Martin Luther's intentions and efforts" 28 .

Another direction worth mentioning was the reference to a renewal of man, or a reorientation towards his humanistic values. This direction has been foundational in Romanian Orthodoxy since Patriarch Justinian Marina purportedly stated: "Christ is the new man. The new man is the Soviet man. Therefore, Christ is Soviet!"

As a result, Martin Luther's personality is praised by the authors of these notes, highlighting his vocation as "a Renaissance man", expressing

His advanced humanistic thinking, creating an ideological base for the bourgeoisie that arose, but was embarrassed by the ties of the Middle Ages. Martin Luther practices an 'aggiornamento'

\footnotetext{
24 Ibidem, p. 940.

25 Ibidem, p. 939.

26 O. Bucevsky, "Pentru pacea a toată lumea”, in: Glasul Bisericii 26 (11-12/1967), p. 1099.

27 Il.I. Georgescu, "Împlinirea a 450 de ani”, p. 940.

28 Ibidem.
} 
for that time with the courage and perspicacity of the man who wants the good and the happiness of all. His limits are the limits of the epoch, but enthusiasm pushed him further, going beyond the ineffective convictions and excommunications of a foreign administration to the reality of that age ${ }^{29}$.

Along the same line is the affirmation of the Russian Patriarchate's representative, Metropolitan Nicodemus, who points out that "through Martin Luther not only Western Christianity, but also humanism has received a new stimulus" ${ }^{30}$.

Though it may seem exaggerated expression or just flattery, but when viewed in the context of that time, Luther's gesture was if not unprecedented (and we are considering the pre-reformers or the other reformers), certainly loaded with the certainty of taking responsibility for a vocation not only at the religious level, but also at the level of humanistic spiritual values. This represented a fundamental moment in the cultural development of Europe and, implicitly, of the world.

Examining the historical event, the authors took the matter from the spiritual dimension of the Reformation to the social one:

At a moment of church imbalance and theological confusion, in an atmosphere of tension and social and political discontent, the action of Wittenberg's Biblical theology professor was interpreted as an open protest, as a challenge to debate, as a call to reform ecclesial life in its entirety. Martin Luther thus became not only the founder of the German Reformation, but also the inspirer of a popular movement of great proportions and profound implications in the European humanist culture ${ }^{31}$.

Despite this last statement, the approach that we find in Studii Teologice The Review of the Faculties of Theology of the Romanian Patriarchy - is much more sensitive and established, insisting that the emergence of the Reformation was determined by an extremely complex context, but it cannot strictly be summarized to socio-economic conditions:

Often the origin of the 16th-century Reformation, as well as that of the Schism of the 11th century, is attributed to 'non-theological' factors, its outbreak being considered a historical-social necessity, or a phenomenon of the German people. Rightly, some consider the abuses of the papal institution at that time as germs of general discontent. Luther himself recognizes the 'chain of circumstanc-

29 Ibidem, p. 939.

30 O. Bucevsky, "Pentru pacea a toată lumea”, p. 1105.

31 S.n., "Consideraţii asupra teologiei”, p. 555. 
es' that led him to oppose church authority. But an event of this magnitude cannot be explained exclusively by these historical or social factors ${ }^{32}$.

On the other hand, it has been constantly emphasized that "although Luther wanted a reform movement in the Church, he did not intend to establish a new Church or sect" ${ }^{33}$, the emergence of the new Church was determined by the brutal reaction of the Papacy, which refused to accept the need for a profound change.

Placing the spiritual and moral causes in an insignificant background would ultimately lead to a distorted picture of the true meaning of the Reformation, ignoring the fact that:

the 95 theses, the manifest, that started profound changes in the life and the thinking of the Church, were meant to purify the ecclesial life, to turn the entire Christian experience into that evangelical purpose at the end of Middle Age ${ }^{34}$.

Analysing Martin Luther's personality, the author reviews the main characteristics of his religious psychology and his complex personality - characterized by a wide range of opinions, objective or arbitrary, describing him as possessed, neurasthenic, obsessed with "concupiscentia carnis", morally unbalanced, dominated by violent temper, but also an inspired interpreter of the evangelical truth, great preacher and exegete, a man with perfect theological culture, who contributed exceptionally to the formation of the German language.

Thus:

From the past unfavorable portrayal aimed at disqualifying Luther's work, the Lutherologists have now gone through an objective examination that takes into account his religious intentions, the theological motives of his protest. 'The Protestant international congresses for studying Luther' have highlighted new positive aspects in the thinking and the work of the German reformer. There has also been a considerable evolution in the attitude of Roman Catholic theologians towards Lutheran theology; the period of 'destructive criticism' was abandoned and the period of 'respectful approach' toward the person and the actions of Luther was inaugurated ${ }^{35}$.

32 Ibidem, p. 556.

33 Ibidem. See also Il.I. Georgescu, "Împlinirea a 450 de ani”, p. 939.

34 Il.I. Georgescu, "Împlinirea a 450 de ani”, p. 939.

35 S.n., "Consideraţii asupra teologiei”, p. 556. 
The attitude regarding the Reformation evolved further over the next 50 years, from a neutral and respectful approach to a relatively open and friendly one. Today, Catholic theologians seem comfortable talking about Luther with Lutherans, even talking with obvious regard and sympathy for Luther. Even Pope Benedict showed how a Catholic can have a certain sympathetic reading of Luther, notwithstanding the same Catholic's rejection of Luther's repudiation of the Catholic Church. In this way, a Catholic can see what is most important when it comes to assessing Luther - not denying the problems with him but also not overlooking what Luther got right or demonizing him ${ }^{36}$.

Having established, these premises concerning the person of Martin Luther, the author of this unsigned text, most probably Father Dumitru Stăniloae, deliberates over the effects of the Reformation, and especially the creation of Protestantism which

is always associated with the reform movement in the Church, and must be considered as a consequence of the Reformation. Secondly, Lutheranism must be considered a way of interpreting Christianity, Luther believing that his doctrine is consistent with the doctrine of the Old Church and that of the Holy Fathers of the Church. The Protestant theology cannot therefore be defined negatively, exclusively as a critique of Roman Catholicism. Undoubtedly, the Reformation began by rejecting some medieval Catholic beliefs and practices, but the reformers' protest is doubled by the positive reaffirmation of the Gospel faith from the beginning, as the recent research emphasizes ${ }^{37}$.

Assessing the main achievements of the Reformation, due to the directions designed by Martin Luther and perpetuated in Protestantism, several important attributes are emphasized as "values of this tradition that cannot be neglected". We remember first and foremost the reconsideration of the place of Holy Scripture in the life of the Church and the liberation from the artificially constructed dogmatic scaffolding, so foreign to ecclesial realities and necessities, implying that

The true doctrine must be cleansed of 'additions', in an age and in a Church where the word of God was subordinated to ecclesial traditions. He (i.e. Martin Luther) criticized scholastic theology because it had transformed the Christian message into a code of doctrines without Biblical basis being meaningless for life. Thus,

36 Mark Brumley, "The Pope, Martin Luther, and Our Time”, The Catholic World Report 25 september 2011, http://www.catholicworldreport.com/2011/09/25/the-pope-martinluther-and-our-time/ viewed on 30.05.2017.

37 S.n., "Consideraţii asupra teologiei”, p. 557. 
Luther, like the other reformers, drew attention to and reintroduced some fundamental notions of ancient Christian doctrine: the authority of Holy Scripture, the importance of faith in the act of salvation, the universal priesthood of believers, evangelical piety. Even though he and his followers did not give the best formulation to all Christian doctrines, it is to the reformers' merit that in a period of medieval scholasticism they promoted the primacy of divine grace, the primacy of the word of God, of faith, of spiritual life. All these values are part of the common heritage of all Christian Churches ${ }^{38}$.

It is important to note how the author chooses to speak in this paragraph about the basic principles of Protestantism summarized by the three solae: sola Scriptura, sola fide, and sola gratia; instead of a term of exclusion (sola, i.e. only) he uses the notion of primacy or preeminence of Scripture, Faith and Grace in ecclesial life.

Another special benefit attributable to Luther's actions is:

The restoration of the Christocentric principle, a fundamental principle in Pauline soteriology, but accomplished by the diminishing of the Church's institutional role, which undoubtedly represents a real reform in the conditions in which Luther tried it. This restoration will remain as a permanent duty of the 'reformats' that the 'Christological concentration', underlined by Karl Barth, can be applied to all Protestant theology. [...] Of course, Luther is right when he considers the relationship between Christ and the believer the central issue of Christian soteriology and when he understands belief as a personal response, not the mechanical acceptance of dogmatic definitions ${ }^{39}$.

A Christocentric ecclesiology is the return to a natural state but forgotten and diverted by organizing a sophisticated hierarchy that destroys the Body of Christ and does not allow Him to be perceived as the Church's true Head. This perception would reduce the presence of our Savior to a purely symbolic aspect that has no real implications at the level of the believers' spiritual life. The reaffirmation of the Christocentric principle means reactivating the personal dimension of faith and moving the emphasis from an institutional relationship to an intimate relationship of the Savior with each person.

And here is the decisive contribution that the Wittenberg professor and preacher had in delivering faith from dogmatic sterility in order to leave room in the Christian life for a personal relationship with the Son of God:

38 Ibidem, p. 559-560.

39 Ibidem, p. 560-561. 
Luther saw in the scholastic theological formulations some barriers that closed the path to the truth, and he revolted against the Catholic dogmatism which had restricted the doctrine through canons, weakening the confession of faith. He understands the act of faith as an experience of the personal encounter between Christ and the believer. Through this Luther can be found to be in the tradition of the great teachers of Christian spirituality since the beginnings, who gave priority to experience over theological formulation ${ }^{40}$.

Naturally, there are some objections to the issue of neglecting orthodox doctrine or the content of faith as a qualitative requirement without which the Christian can estrange himself from the source of life, the Personal Truth, and Sola fide involves the risk of concentrating on his own spiritual evolution, isolating the Christian from the world and his brothers, cancelling communion and personal relationship with his fellow. Similarly, the theory of imputation and justification by faith is criticized, by which Luther remains in a unilateral aspect of soteriology, but also the fact that, when he tries to theorize the faith, all the ontological and ethical aspects of the presence of Christ in us are not attained.

In another unsigned text behind which Father Stăniloae appears to be found, the potential of Protestantism is fully stressed, which

would be true to his original intention and would bring a true and genuine contribution to Christian spirituality if he deepened the idea of man's value, the deep mystery of his freedom, meditating on all the conditions in which man can update his wonderful position, as crown of God's creation, called to His knowledge and to eternal communion with $\mathrm{Him}^{41}$.

The passage insists on the value of man conferred by the freedom to manifest its ability to be a propagator of the Divine Revelation ${ }^{42}-$ a fundamental thesis of Father Staniloae's anthropology. The possibility of emphasizing this divine calling on updating God's image as a resemblance to Him in a way that the Orthodox and Roman Catholic Church have not realized until then represents the immense contribution of the Reformation.

Referring also to a genuine participation of Orthodoxy in this event, it was natural to proceed from the two basic principles of eastern symbolic theology for the interpretation and determination of doctrinal differences of various confessions in the whole of Christianity:

$40 \quad$ Ibidem, p. 563.

41 S.n., "Comemorarea Reformei”, p. 492.

42 Dumitru Stăniloae, Iisus Hristos sau restaurarea omului, Craiova ${ }^{3}$, IBMBOR 1993, p. 19. 
a) the principle of dogmatic consensus - consensus fidei - regarding the fundamental elements that make up the ecclesial constitution of Christ's Body; and b) the principle of variety or diversity in the structural unit ${ }^{43}$.

Starting from these premises and on the basis of the ecclesial contacts that created the possibilities of a dialogue in order to reinterpret interconfessional divergences, the representatives from the Orthodox side contributed with

valuable studies on the history of the relations between Orthodoxy and Protestantism in order to discover their common values as well as ways of interpreting their specific traditions in the light of what unites them, and clarifying the limits of the 16th century Reformation ${ }^{44}$.

Leaving aside the theory of confessional patronage ${ }^{45}$ that moves the emphasis from unity to diversity, advocating for maintaining the divergences ${ }^{46}$, it is more than obvious to the authors of those notes that there are affinities between Protestantism and Orthodoxy, affinities that ease ecumenical contacts between them ${ }^{47}$, overcoming the formal distinction between 'Traditionalist Christianity' - Orthodoxy and 'Liberal Christianity' - Protestantism ${ }^{48}$.

Moreover, the relationship between the two families of Christian Churches revealed after about half a century that at the time of the 450th anniversary of the Reformation there was

Not only a 'nostalgia for Orthodoxy', but also a real interest from the Protestant theologians towards the Orthodox Church. Some Protestant theologians find, for example, that the difference between Orthodoxy and Reform lies in the form given to the answer of faith. In the Eastern Church, dogma was first determined by the 'doxological element' of the confession of faith, while in the Churches of Reformation it was determined by the 'kerygmatic element' ${ }^{49}$.

43 S.n., "Consideraţii asupra teologiei”, p. 557.

44 Ibidem.

45 This refers to the so often quoted analogy, according to which Orthodoxy inherits the spirit of the Apostle John, the spirit of love, Roman Catholicism the one of the Apostle Peter, the authoritarian spirit, and Protestantism the one of the Apostle Paul, the liberal and autonomist spirit. The exaggerated use of this theory leads to the impression that the confessional divergences are justified in a certain divergence of character and attitude among the three Apostles.

46 S.n., "Consideraţii asupra teologiei", p. 558.

47 Il.I. Georgescu, "Împlinirea a 450 de ani", p. 941.

48 S.n., "Consideraţii asupra teologiei”, p. 559.

49 Ibidem. 
The sincere discovery of alterity or otherness was caused by the necessity of practicing an ecumenical 'aggiornamento' in response to the decisions of the Second Vatican Council so that "at the celebration of the 450th anniversary of the beginning of the Reformation, Western Christianity passes through a theological kneading that causes some to speak of a 'new Reform"' ${ }^{0}$. This concept was not a novelty, since

the essence of the Reformation consisted of a renewal, a transformation of the Church, and this tendency has to be continually asserted, and if the Churches feel attracted to one another, it is because they have revealed the value and universal-Christian necessity of the Protestant principle of a Reformation, of a continuous renewal (Ecclesia semper reformanda). Pastor G. Richard-Molard says: 'The 16th century reform has been a scandalous break for the world. The new 20th-century Reform, the only possible answer to the challenge of our time, might give the Church, in addition to this and through unforeseen ways, the unity that its Lord wants' ${ }^{2}$.

The drawback of this vision is the idealization of the concept of renewal that has become a purpose in itself. The human component of the theandric institution - the Church - is experiencing a permanent temptation of "better", being tempted to seek easy improvements in order to respond to fictitious needs, and ultimately proving unnecessary, just to exhaust resource and time, which could be channelled to real necessities. This perpetual search for new things, new concepts and new directions betrays the human inconstancy in general, and indicates a predilection for an unending change, but not necessarily for good, that is why:

the meaning of this incessant Reform is so poorly stated by Protestant theologians who recommend it, that the Reform continues to be considered valuable by itself. Being always new becomes an ideal by itself. No concern for truth seems to animate this passion for permanent novelty ${ }^{52}$.

This ignores a principle of common sense according to which "in general all Churches can be renewed continuously only in the truth", a truth guaranteed by Church Tradition and the texts of the Holy Fathers ${ }^{53}$.

\footnotetext{
50 Ibidem, p. 563.

51 S.n., "Comemorarea Reformei”, p. 492.

52 Ibidem.

53 Ibidem.
} 


\section{Conclusions}

Since that moment, the openness to ecumenical dialogue and knowledge of the other denominations became a priority for the Romanian Orthodox Church in the 1970s, noting in particular the predilection for studying certain aspects of Protestantism that went beyond the level of symbolic theology and defensive argumentation ${ }^{54}$. Moreover, the issue of the contribution of Romanian theological culture to the dialogue and understanding of those particularities that define the Protestant Churches ${ }^{55}$ has been constantly raised, as well as the need for participation in the Official Theological Dialogue between the Orthodox Church and the World Lutheran Federation (1982-1987).

The 50 years ago anniversary reveals once again the close link between ecclesial life and the social and political framework in which the Church operates. The materials presented, drafted, some of complaisance in order to check the directions given by the Department of Cults, others written with critical spirit and interest give us important clues as to how Protestantism was received in the Romanian Orthodox Church. At the same time, they allow us to assess the degree of genuine and disinterested involvement of Orthodoxy in the ecumenical movement at that time, but also to properly appreciate the motivation and effort we make today in interconfessional dialogue, making it clear that we have now a privileged framework, auspicious to genuine feelings of brotherly love.

54 This is evidenced by several doctoral theses written in the 1970 s worth mentioning; i.e., the thesis of $\dagger$ Antonie Plămădeală, "The Servant Church in Sacred Scripture, in Tradition and in Contemporary Theology", Deac. P.I. David, "The Perspectives of the Anglican-Orthodox Dialogue: The Divine Revelation. Contribution of Romanian Theological Culture", Rev. Dumitru Colotelo, "The Liturgical Movement in Western Christianity", or $\dagger$ Daniel Ciobotea, "Christian Theology and Spirituality. The relationship between them and the current situation", which explores topical themes for contemporary Christianity at the interconfessional level. Recently there can be noticed a concern dedicated to the impact of the Reformation on the cult of the Orthodox Church in Transylvania; i.e., Paul Brusanowski, "Curentul bisericesc reformator din secolul XVII şi începutul românizării cultului BOR”, in: TABOR I (7/2007), p. 40-50 and Ciprian Streza, "The Translation of Liturgical texts into the Oral Language within the 17th century Transylvanian Liturgical Tradition. The Emergence of the Romanian Euchologion amid Culturally and Confessionally Challenged Times", in: Teologia 66 (1/2016), p. 10-42.

55 See the discussions held during the 35th Interconfessional Theological Conference on 22nd-23rd May 1980 in Bucharest cf. Ştefan Gănceanu, "A 35-a Conferinţă Teologică Interconfesională", in: Studii Teologice 32 (3-6/1980), p. 685-707, with the special contribution of Dr. Christoph Klein regarding the presentation and the explanation of the Holy Sacraments in the Evangelical Church A.C., Ibidem, p. 707-714. 